\title{
Colonization and community changes in benthic macroinvertebrates in Cheonggye Stream, a restored downtown stream in Seoul, Korea
}

\author{
Il Kwon Shin ${ }^{1,2}$, Hoon Bok Yi ${ }^{2}$ and Yeon Jae Bae ${ }^{1,3, *}$ \\ ${ }^{1}$ Korean Entomological Institute, Korea University, Seoul 136-701, Korea \\ ${ }^{2}$ Division of Environmental and Life Science, Seoul Women's University, Seoul 139-774, Korea \\ ${ }^{3}$ Division of Life Sciences, College of Life Sciences and Biotechnology, Korea University, Seoul 136-701, Korea
}

\begin{abstract}
Colonization patterns and community changes in benthic macroinvertebrates in the Cheonggye Stream, a functionally restored stream in downtown Seoul, Korea, were studied from November 2005 to November 2007. Benthic macroinvertebrates were quantitatively sampled 15 times from five sites in the stream section. Taxa richness (59 species in total) increased gradually over the first year, whereas the density revealed seasonal differences with significantly lower values in the winter season and after flood events. The benthic macroinvertebrate fauna may have drifted from the upstream reaches during floods and from the Han River, arrived aerially, or hitchhiked on artificially planted aquatic plants. Oligochaeta, Chironommidae, Psychodidae, and Hydropsychidae were identified as major community structure contributors in the stream. Swimmers and clingers colonized relatively earlier in the upper and middle reaches, whereas burrowers dominated particularly in the lower reaches. Collector-gatherers colonized at a relatively early period throughout the stream reaches, and collector-filterers, such as the net-spinning caddisfly (Cheumatopyche brevilineata), predominated in the upper and middle reaches after a 1-year time period. Cluster analyses and multi-response permutation procedures demonstrated that the Cheonggye Stream shares more similarities with the Jungnang Stream than with the Gapyeong Stream. Detrended correspondence analysis and nonmetric multidimensional scaling demonstrated that physical environmental factors (depth, current velocity, dissolved oxygen, and $\mathrm{pH}$ ) as well as nutrients (total nitrogen and total phosphorous), water temperature, and conductivity could affect the distribution of benthic macroinvertebrates in the study streams.
\end{abstract}

Key words: aquatic insects, artificial stream, functional groups, habitat rehabilitation, stream restoration, urban stream

\section{INTRODUCTION}

Stream restoration has become a popular management strategy for improving the physical and ecological conditions of regulated urban streams, as streams and rivers are the most vulnerable ecosystems that humans impact (Allan and Castillo 2007, Bernhardt and Palmer 2007). Stream restoration projects in urban areas have increased in number and importance in recent years, due to growing awareness of conservation, management, and other public benefits, including recreational, aesthetic, and economic factors (Brown 2000). A number of studies have demonstrated that a loss of habitat diversity caused by channelization negatively influences the abundance and richness of stream biota, including fishes and macroinvertebrates. Therefore, considerable efforts

\section{Open Access DOI: 10.5141/JEFB.2011.020}

This is an Open Access article distributed under the terms of the Creative Commons Attribution Non-Commercial License (http://creativecommons. org/licenses/by-nc/3.0/) which permits unrestricted non-commercial use, distribution, and reproduction in any medium, provided the original work is properly cited.
Received 23 August 2010, Accepted 07 January 2011

*Corresponding Author

E-mail: yjbae@korea.ac.kr

Tel: +82-2-3290-3408 
have been devoted to restoring these degraded streams to conditions closer to their natural state (Malmqvist et al. 1991, Quinn et al. 1992, Bis et al. 2000, Brown 2000, Muotka et al. 2002, Purcell et al. 2002, Moerke et al. 2004, Alexander and Allan 2006, Nakano et al. 2008).

The Korean peninsula has experienced rapid environmental degradation beginning in the 1960s, at which time the Korean government launched a land development program (Bae et al. 2005). However, the land development trend slowed when the Korean government began promoting nature conservation and restoration in the 1990s. The "Cheonggye-cheon (Cheonggye Stream) restoration project" in downtown Seoul is a symbolic event in this regard. This project was planned as a city redevelopment program in an old city district in Seoul to provide clean water flow passing through the center of the city. However, this project triggered nation-wide biomonitoring and stream restoration efforts in Korea, and hundreds of urban or suburban streams are currently undergoing restoration procedures throughout Korea. Stream restoration is currently one of the most pressing social and political issues in Korea.

Benthic macroinvertebrates are good indicator organisms for biomonitoring water quality and instream environments of stream ecosystems (Rosenberg and Resh 1993). Numerous biomonitoring studies have been conducted in natural and regulated streams and rivers, but changes in the colonization and communities of benthic macroinvertebrates in restored urban streams have not been studied thoroughly thus far. Creating an artificial stream channel, as in the functionally restored Cheonggye Stream, has provided a unique opportunity in this regard.

The objective of this study was to assess the colonization patterns and community changes in benthic macroinvertebrates in the Cheonggye Stream with regard to chronological changes in community structure, functional groups, and indicator species or species groups, via a 2 -year field investigation that was undertaken since the initial flow after construction.

\section{MATERIALS AND METHODS}

\section{Historical background of the Cheonggye-cheon restoration project}

The Cheonggye Stream originates from the Inwangsan (Mt.) and Bukaksan (Mt.) areas located north of Seoul. The main stream follows the west-east axis through downtown Seoul and merges into the lower reach of the Jungnang Stream, which empties into the Han River (Fig. la and $1 \mathrm{~b}$ ). The total length of the Cheonggye Stream is approximately $11 \mathrm{~km}$. The area includes urban structures and many office buildings.

The Cheonggye-cheon area is one of the most populated areas in Seoul, as this area has historically been a commercial and business center of the city since the beginning of the Joseon dynasty in 1392 (Figs. 1b and 2a). Between 1955 and 1977, an approximate 6-km stretch of the mainstream channel was cement paved from Gwangtong-gyo (bridge), near Seoul city hall, to Sindap-cheolgyo (a railroad bridge), approximately $6 \mathrm{~km}$ downstream from city hall (Fig. 2b). Additionally, a $5.6 \mathrm{~km}$-long, 16-m wide elevated highway extending from Gwanggyo to Majang-dong, throughout the cement-paved section of the stream, was completed over the stream in August 1971, after 4 working years (Fig. 2c). In July 2003, Mr. Lee Myung-bak, then-Seoul mayor and current President of Korea, initiated a project to remove the cement-paved road and the elevated highway and to restore the stream. The stream was opened to the public on October 1, 2005 and was lauded as a major success (Fig. 2d).

Prior to the restoration effort, the main stream was covered completely by a road structure, with an elevated highway over the road, and an intercept sewage system under the road. During the 2-year restoration project conducted from July 2003 to September 2005 (budget, 386,000 million won), a $5.8-\mathrm{km}$ section of the stream extending from Taepyeong-no, near city hall, to Sindapcheolgyo was artificially reconstructed. As the Cheonggye Stream is an intermittent stream, and is normally dry, it requires additional flow to maintain a maximum 40$\mathrm{cm}$ depth of water throughout the year. Approximately $120,000 \mathrm{t}$ of water per day is supplied from the Han River $(98,000 \mathrm{t})$ as well as from the subway groundwater system (22,000 t) to maintain the water level (http://cheonggye. seoul.go.kr).

The restored Cheonggye Stream consists of a series of pool-riffle sequences. These riffles are 10-20 m long, with a mean depth and current velocity $(20 \mathrm{~cm}$ above the bottom) of $0.24 \mathrm{~m}$ (standard deviation $[\mathrm{SD}], \pm 0.09$ ) and 1.14 $\mathrm{m} / \mathrm{s}(\mathrm{SD}, \pm 0.30$ ), respectively. Riparian plants were artificially planted, but some trees, including Salix gracilistyla and S. koreensis, have been colonized along the stream banks, although the main bankside vegetation is grass.

\section{Study sites}

Five study sites along the restored section of the 

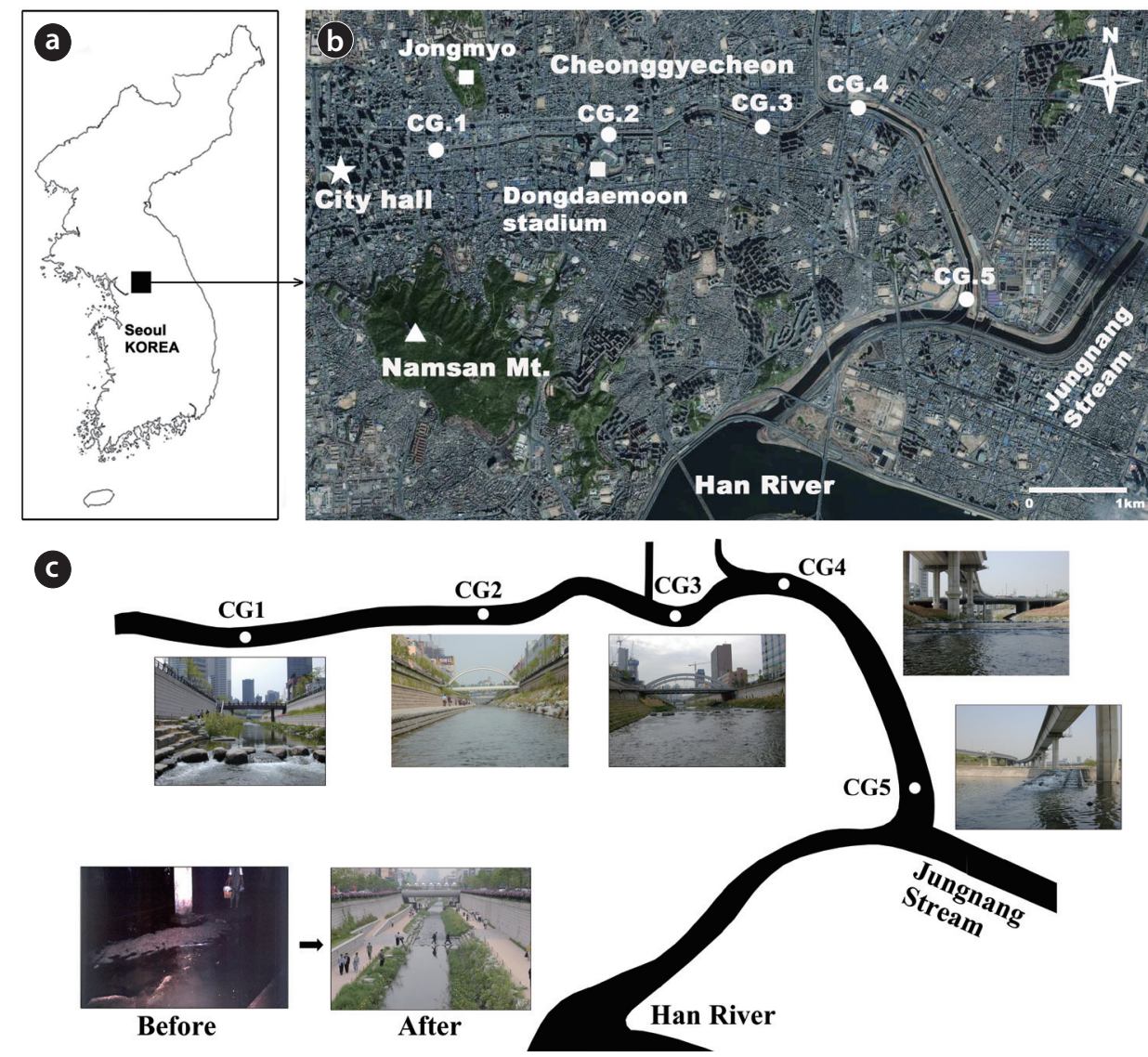

Fig. 1. Study sites in the Cheonggye (CG) Stream in Seoul, Korea. (a) Korean peninsula. (b) downtown Seoul. (c) study sites. The five sampling sites are indicated as CG1-CG5.
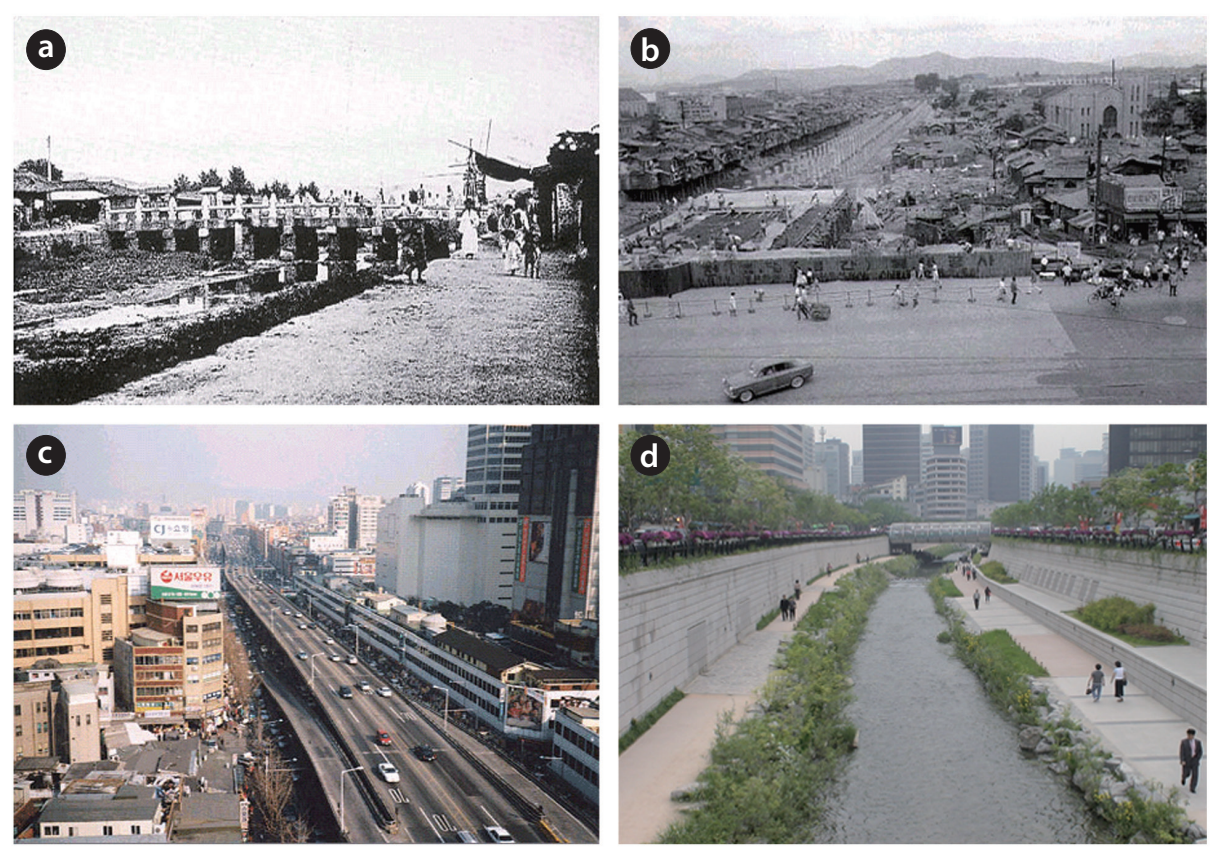

Fig. 2. Centennial changes in Cheonggye Stream, an urban stream in downtown Seoul, Korea. (a) In the early 1900s, (b) in the 1960s when a cement pavement (culvert) project was launched, (c) in 2003 showing elevated motorways on a paved watercourse, (d) in October 2005 after the restoration project. (a-c): downloaded from Seoul city homepage (http://cheonggye.seoul.go.kr). 
Cheonggye Stream, situated $1 \mathrm{~km}$ (Supyogyo, CG1: N

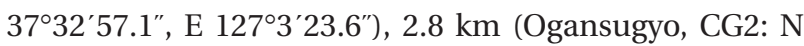
$37^{\circ} 32^{\prime} 57.1^{\prime \prime}$ E $\left.127^{\circ} 3^{\prime} 23.6^{\prime \prime}\right), 4.4 \mathrm{~km}$ (Biudanggyo, CG3: N 37 $34^{\prime} 3.7^{\prime \prime}$, E $\left.127^{\circ} 1^{\prime} 47.5^{\prime \prime}\right), 5.5$ km (Gosanjagyo, CG4: $\mathrm{N} 37^{\circ} 34^{\prime} 10.9^{\prime \prime}, \mathrm{E} 127^{\circ} 2^{\prime} 29.2^{\prime \prime}$ ), and $8 \mathrm{~km}$ (Jungnang in-

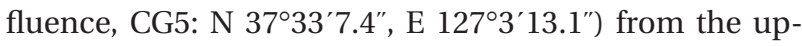
permost initial flow (hereafter referred to as CG1-CG5, respectively), were selected for sampling. The CG1-CG4 sites were located inside the past cement-paved section of the Cheonggye Stream. These study sites represented habitat types in the upstream (CG1 and CG2), midstream (CG3 and CG4), and downstream reaches (CG5) of the Cheonggye Stream (Fig. 1c).

We sampled two source streams, the Bukaksan (Mt.) Stream and the Han River to evaluate potential sources of benthic macroinvertebrate colonizers. The Bukaksan Stream is a headwater stream originating from the $\mathrm{Bu}$ kaksan (alt. $343 \mathrm{~m}$ above sea level, located approximately $3 \mathrm{~km}$ north of the Cheonggye Stream) and connected to the main Cheonggye Stream. Most branch streams of the Cheonggye Stream inside the urban area of Seoul, including the Bukaksan Stream, are channelized with cementpaved road structures, and the water flows only when precipitation is sufficient (rainy season). The Han River site, located approximately $5 \mathrm{~km}$ upstream from the confluence of the Jungnang Stream, is the site to which the source water is supplied.

We also sampled two reference streams, the Jungnang Stream (three sites) and the Gapyeong Stream (two sites) to compare benthic macroinvertebrate communities. The Jungnang Stream is a nearby urban stream to which the Cheonggye Stream merges, and the Gapyeong Stream is a natural stream located approximately $60 \mathrm{~km}$ from Seoul. The sampling sites are as follows: Jungnang Stream (JR): JR1 (Nowon-gyo: N 37'32'57.1", E 127'3'23.6"),

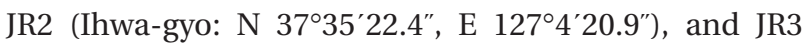
(above Cheonggye Stream confluence: N 370 $40^{\prime} 35.4^{\prime \prime}, \mathrm{E}$ $\left.127^{\circ} 3^{\prime} 10.5^{\prime \prime}\right)$; Gapyeong Stream (GP): GP1 (Seungcheonsa: N $37^{\circ} 56^{\prime} 3.8^{\prime \prime}$, E $127^{\circ} 29^{\prime} 12.5^{\prime \prime}$ ) and GP2 (Seonbawi: N $37^{\circ} 56^{\prime} 13.6^{\prime \prime}$, E $\left.127^{\circ} 29^{\prime} 21.8^{\prime \prime}\right)$.

\section{Field survey and sampling}

Field investigations were conducted from November 2005 to November 2007 at five study sites in the Cheonggye Stream. The first year's (November 2005-November 2006) sampling was monthly, whereas sampling was conducted seasonally during the second year (February 2007, April 2007, August 2007, and November 2007). Reference streams (Jungnang and Gapyeong) were sampled in April
2006 and April 2007. The two source streams (Bukaksan and Han River) were sampled once in October 2006 to determine the origin of the Cheonggye Stream fauna.

Benthic macroinvertebrates were sampled quantitatively using a Surber sampler $(50 \times 50 \mathrm{~cm}$; mesh $0.2 \mathrm{~mm}$; 1 riffle, 1 run/pool, and 1 margin habitat sample per site; total sampling area $7,500 \mathrm{~cm}^{2}$ per site); the samples from three habitat types were pooled for statistical analyses. Marginal sampling was taken within a 1-m area from the bank at which the flow was very slow, and aquatic macrophytes were present. However, these marginal sampling data were not used for comparisons with reference stream sites because the bank structures of the artificial and natural streams were fundamentally different. The samples were preserved with Kahle's solution and transported to the laboratory for sorting and identification. Benthic macroinvertebrates were identified to the species level using available references (McCafferty 1981, Wiederholm 1983, Yoon 1995, Merritt and Cummins 1996, Kawai and Tanida 2005). Other sampling and habitat investigation methods were conducted in accordance with general protocols (Ward 1992, Williams and Feltmate 1992, Merritt and Cummins 1996, Allan and Castillo 2007). Benthic macroinvertebrates were assigned to a habitat orientation group and a functional feeding group (Merritt and Cummins 1996).

\section{Data analyses}

Benthic macroinvertebrate communities were analyzed using quantitative sampling data in relation to the environmental data. We initially evaluated responses of macroinvertebrate taxa and groups using a site (block) in time approach and analyses of variance (ANOVA) with the SAS program (Sokal and Rohlf 1994). Logarithmic transformations were applied to satisfy the ANOVA assumptions. ANOVA was used to test for differences in mean abundance, mean species richness, and mean species diversity in the macroinvertebrate community (SAS Institute 2001). An ANOVA was used to compare the chronological changes and distributional differences in macroinvertebrate communities (Smith and Smith 2001). F-statistics were calculated for site, season, and the interactions. The level of significance was at least $P=$ 0.05 (SAS Institute 2001).

The averaged data were examined for the multivariate analyses with PCORD ver. 4.28 (McCune and Grace 2002). The main matrix for each sample had high beta diversity, moderate-to-extreme row and column skewness, and a high coefficient of variation among the sums of the 
columns (species) in the matrix. We deleted rare species that occurred in less than $5 \%$ of the samples and applied a logarithmic transformation.

We used detrended correspondence analysis (DCA) and nonmetric multidimensional scaling (NMS). DCA was used to determine the number of factors structuring the complex macroinvertebrate community and to qualitatively summarize the overall distribution of species assemblages across the gradients of different areas (Hill and Gauch 1980). Sorensen's distance measure was used in species space. NMS (Kruskal 1964, Mather 1976, Clarke 1993) is an iterative method based on rank distances between sample units. It is useful for ecological gradient studies because of its general robustness and lack of assumptions about the distribution or type of data. Therefore, NMS was used to determine the number of factors in the complex macroinvertbrate community structure and to qualitatively summarize the overall distribution of species assemblages across the gradients of Cheonggye Stream changes. We examined 13 variables to identify which had the highest correlation coefficients. The variables used included two categorical variables (date and site) and 11 quantitative variables (water flow width, depth, velocity of riffle, velocity of run/pool, water temperature, $\mathrm{pH}$, dissolved oxygen [DO], conductivity, total phosphorous, total nitrogen, and chlorophyll $a$ ).

Simple repeated-measure designs, which are common in ecology, require a multiresponse permutation procedure (MRPP) (McCune and Grace 2002). The MRPP analysis assigned the observed values randomly to different sites (blocks). We could use MRPP because our research fit the analysis of block differences well. This procedure is useful for analyzing ecological data because it does not require assumptions of normality and constant variance (Biondini et al. 1988, McCune and Mefford 1999).

Cluster analyses were conducted using presence/absence data from the five sites in the Cheonggye Stream (quantitative data) and from the reference sites separately for April 2006 and April 2007. Normalized Euclidian distances were computed for the most distant site pairs (complete linkage) (Wilkinson 1988).

\section{RESULTS}

\section{Stream environments}

The general habitat environments at the study sites are shown in Table 1. As the Cheonggye Stream was constructed in the form of a straightened channel with as- sembled bedrock pieces and an artificial water supply, water flow width, depth, and velocity remained almost constant throughout the year. However, during sudden heavy rainfall (approximately $>100 \mathrm{~mm}$ per $\mathrm{h}$ ), the stream water overflowed over the walkways beside the stream banks in the upper and mid-stream reaches immediately after a rainfall. In general, the upper stream reach (CG1 and CG2) was relatively steeper and narrower, with a faster current velocity than the lower stream reach. Yearly average water temperature was relatively lower and DO levels were relatively higher in the upper sampling sites, but the differences between the sites were not so profound. Conductivity, nutrient (total nitrogen and total phosphorus), and $\mathrm{pH}$ levels were somewhat higher than that observed in other natural reference streams. Attached algae (Oscillatoria spp., Phormidium sp. Cocconeis sp., Navicular sp., Scenedesmus spp., Microspora sp., Stephanodiscus sp., etc.) were observed abundantly in the spring season.

\section{Benthic macroinvertebrate faunas and commu- nities}

Fifty-nine species of benthic macroinvertebrates were sampled from the Cheonggye Stream study sites over the study period (Appendix 1). In the reference streams, 10 and 66 species were detected in the Jungnang and Gapyeong streams, respectively. Twenty-two species were detected from the Bukaksan Stream and the Han River, from which the benthic macroinvertebrate fauna may have originated.

The cumulative species number at the study sites, and at the middle and lower stream sites (CG3-CG5) in particular, increased very rapidly during the initial 1-month period, but the rate of increase gradually slowed over the following years (Fig. 3). Larger numbers of benthic macroinvertebrate species were detected in the middle stream sites (CG3 and CG4) than the upper (CG1 and CG2) and lower study sites (CG5).

Taxa richness differed significantly among the five Cheonggye Stream sites $(P<0.001, P=0.0083$, respectively, by the $F$-test), whereas the density and Shannon diversity index did not significantly differ among them (Table 2). Taxa richness, density, and Shannon diversity index values at the middle stream site (CG3) were relatively higher than those at other sites. Taxa richness at the lower stream site (CG5) and density at the upper stream sites (CG1 and CG2) were relatively lower than those at other sites.

Taxa richness and density following 15 samping tri- 


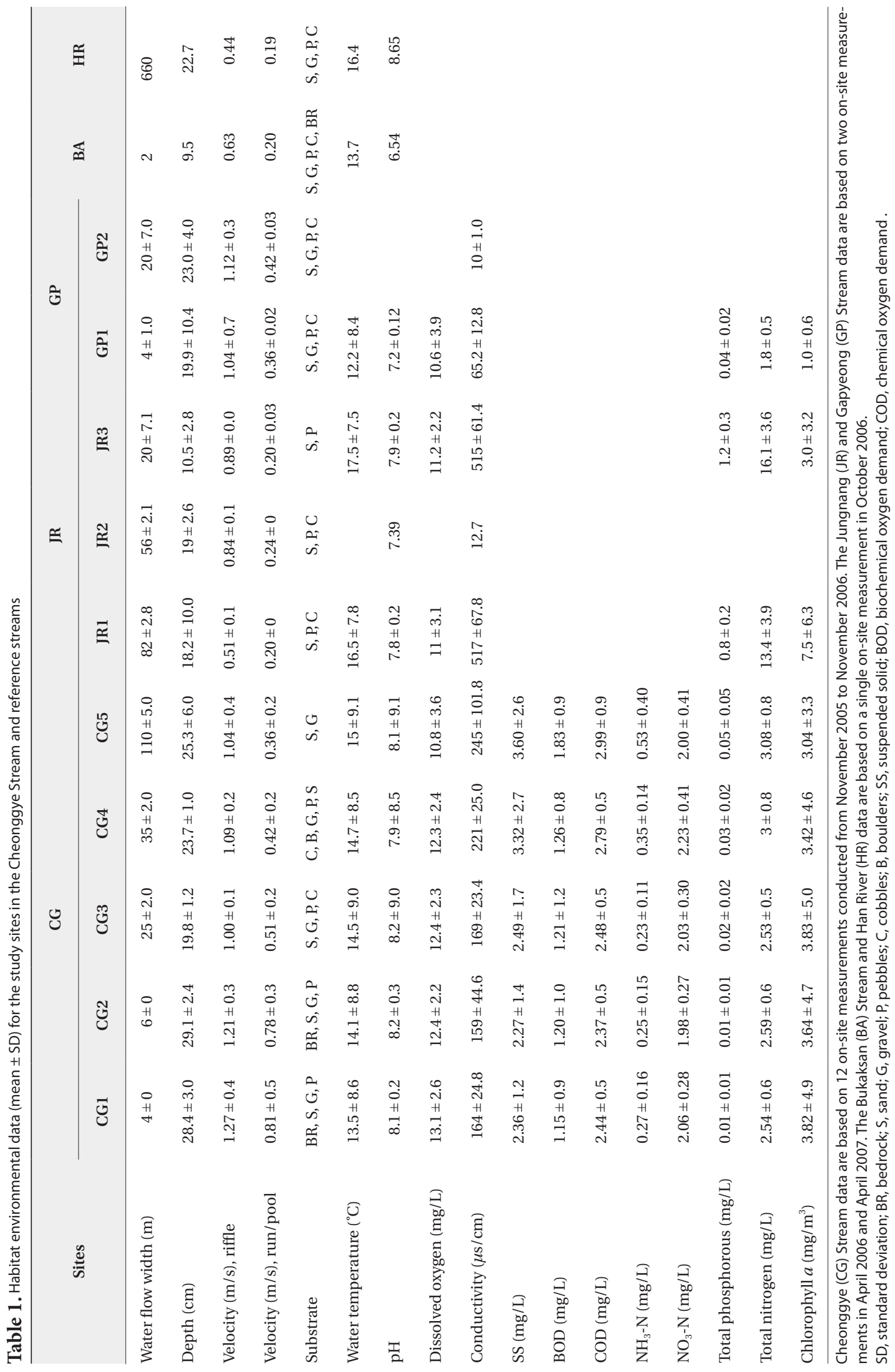




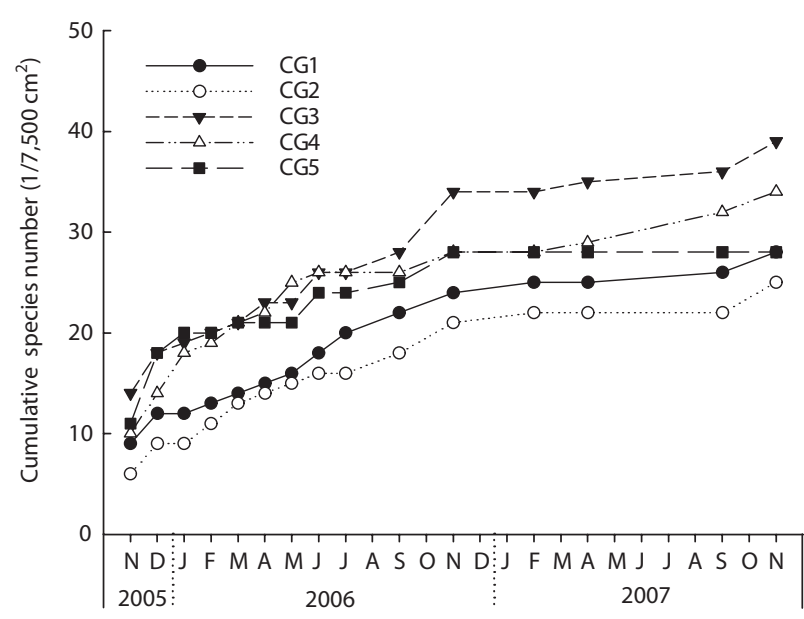

Fig. 3. The cumulative species numbers sampled in the Cheonggye (CG) Stream during the study period. Species number data are based on the sum of three habitat samples (riffle, run/pool, and margin).

als over 2 years (November 2005-November 2007) at the five Cheonggye Stream sites differed significantly $(P<$ 0.0001 and $P=0.0423$, respectively, by the $F$-test), but the Shannon diversity index did not differ significantly (Fig. 4). Taxa richness generally increased gradually during the first year, whereas density showed a seasonal difference. Significantly lower density values were observed during the winter season (January and February 2006 and Februray 2007) and after flood events (July 2006 and August 2007) than at other times. High-density benthic macroinvertebrate taxa, including Oligochaeta (Tubificidae sp.), Chironommidae (Chironominae spp.), Baetidae (Baetis fuscatus), Psychodidae (Psychoda KUa), and Hydropsychidae (Cheumatopsyche brevilineata), contributed significantly to the formation of community structures in the stream section.

\section{Colonization patterns and community changes}

At the first sampling trial in November 2005, aquatic
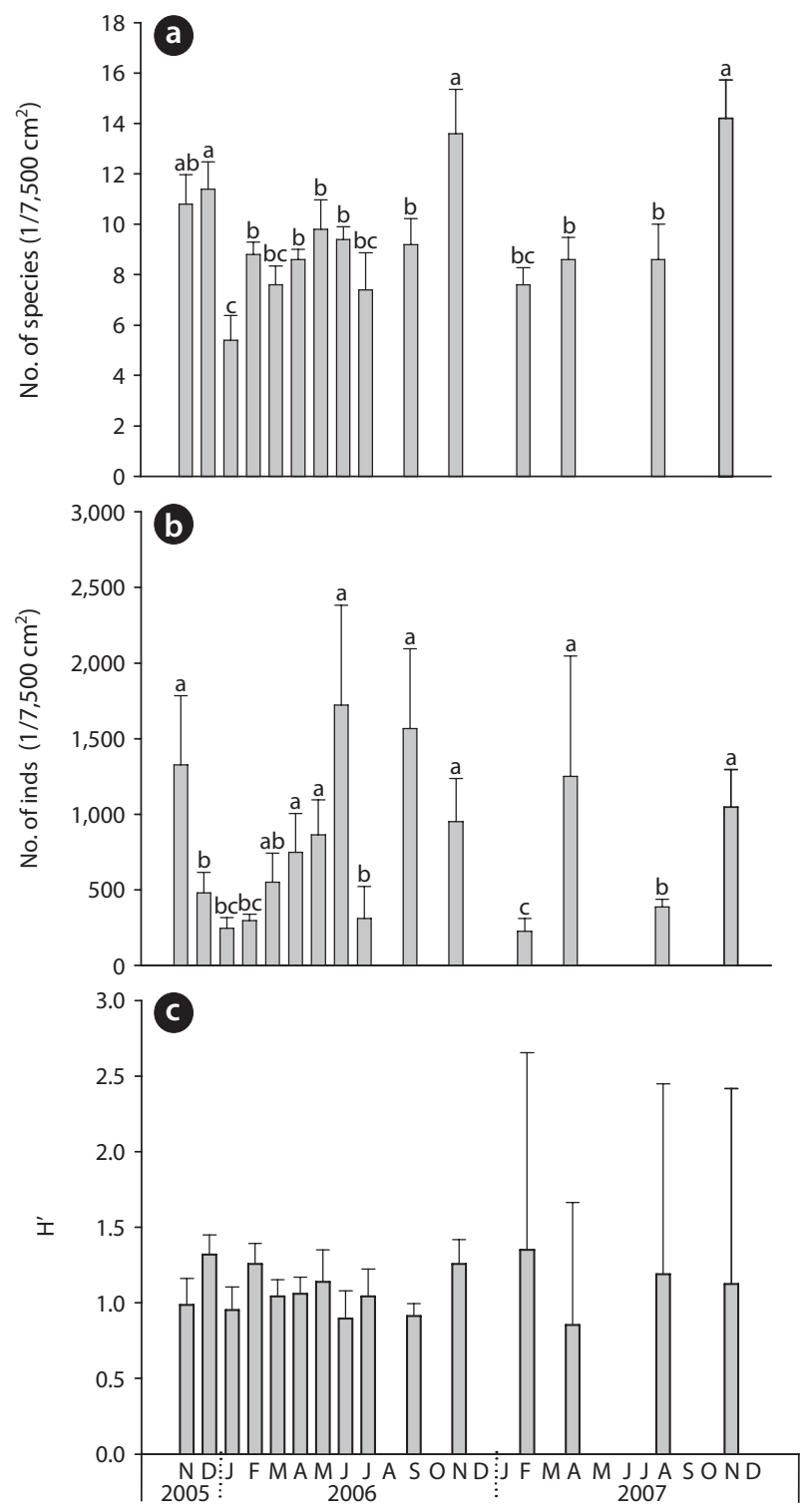

Fig. 4. Mean biotic variable values ( $\pm \mathrm{SE}$ ) according to sampling trials in the Cheonggye Stream. Mean data are based on the mean of five sampling sites with the sum of three habitat samples (riffle, run/pool, and margin) per site. (a) Taxa richness (no. of species) $(F=4.55, P<0.0001)$, (b) density (no. of individuals) $(F=1.92, P=0.042)$, and (c) Shannon diversity index $\left(\mathrm{H}^{\prime}\right)(\mathrm{NS})$. SE, standard error; NS, no statistically significant difference.

Table 2. Mean biotic variable values ( \pm SE) according to sampling sites in the Cheonggye Stream (CG)

\begin{tabular}{cccc}
\hline$\left(H^{\prime}\right)$ & Taxa richness $(\boldsymbol{F}=\mathbf{5 . 1 6}, \boldsymbol{P}=\mathbf{0 . 0 0 1 1})$ & Density (NS) & Shannon diversity $(\boldsymbol{F}=\mathbf{3 . 7 3 , P = \mathbf { 0 0 0 3 } )}$ \\
\hline CG1 & $8.9 \pm 0.6^{\mathrm{b}}$ & $767.7 \pm 326.2$ & $1.2 \pm 0.1^{\mathrm{a}}$ \\
CG2 & $8.3 \pm 0.7^{\mathrm{ab}}$ & $679.4 \pm 303.7$ & $1.1 \pm 0.1^{\mathrm{a}}$ \\
CG3 & $11.8 \pm 1.0^{\mathrm{a}}$ & $2,002.4 \pm 962.7$ & $1.22 \pm 0.1^{\mathrm{a}}$ \\
CG4 & $10.3 \pm 0.6^{\mathrm{a}}$ & $1,537.8 \pm 680.5$ & $1.12 \pm 0.1^{\mathrm{a}}$ \\
CG5 & $7.7 \pm 0.7^{\mathrm{b}}$ & $1,655.4 \pm 729.8$ & $0.82 \pm 0.1^{\mathrm{ab}}$ \\
\hline
\end{tabular}

Mean data are based on the mean of 15 sampling trials with the sum of three habitat samples (riffle, run/pool, and margin) per site. $\mathrm{SE}$, standard error; NS, no statistically significant difference. 

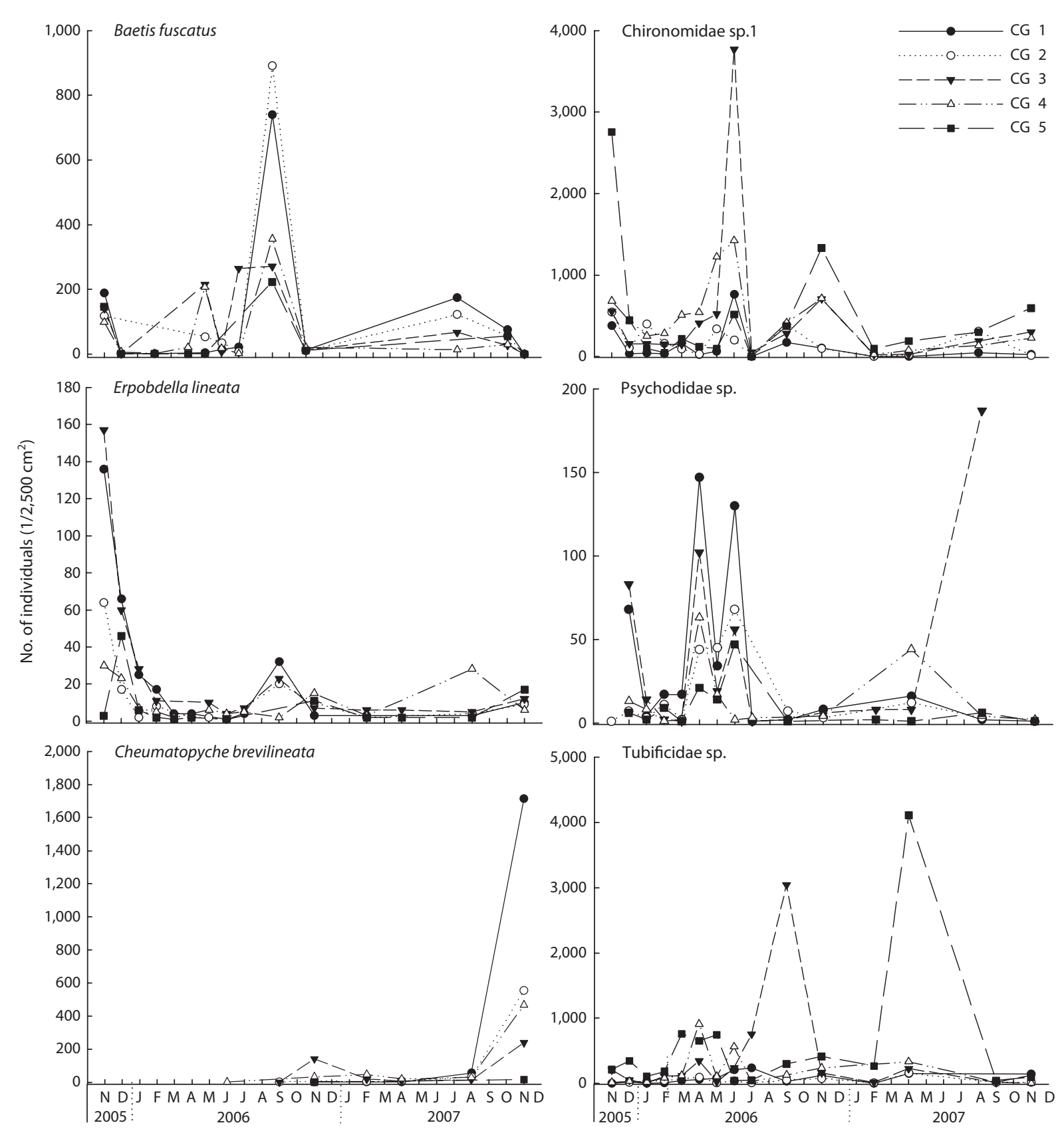

Fig. 5. Chronological density change in six dominant macroinvertebrate species in Chonggye (CG) Stream. Individual numbered data are based on sum of three habitat samples (riffle, run/pool, and margin).

insect taxa such as the Ephemeroptera, Trichoptera, Chironomidae, and Odonata colonized rapidly, and Plecoptera, Hemiptera, and Coleoptera occurred subsequently over the first 6-month period. Other benthic macroinvertebrates, including Oligochaeta, Gastropoda, Hirudinea, and Turbellaria were also detected during the initial time period. A large number of Chironomidae, Oligochaeta, and Baetidae $(57.6 \%, 26.9 \%$, and $9.1 \%$, respectively) occurred throughout the study period, whereas other aquatic insects and benthic macroinvertebrate taxa, including Hemiptera, Plecoptera, Odonata, Coleoptera, Gastropoda, Hirudinea, and Turbellaria remained at relatively lower abundance throughout the entire study period.

Dominant species in the Cheonggye Stream differed depending on site and time (Fig. 5). A chironimid species (Chironominae sp. 1) and a tubificid worm (Tubificidae sp.) occurred abundantly throughout the study sites, but 


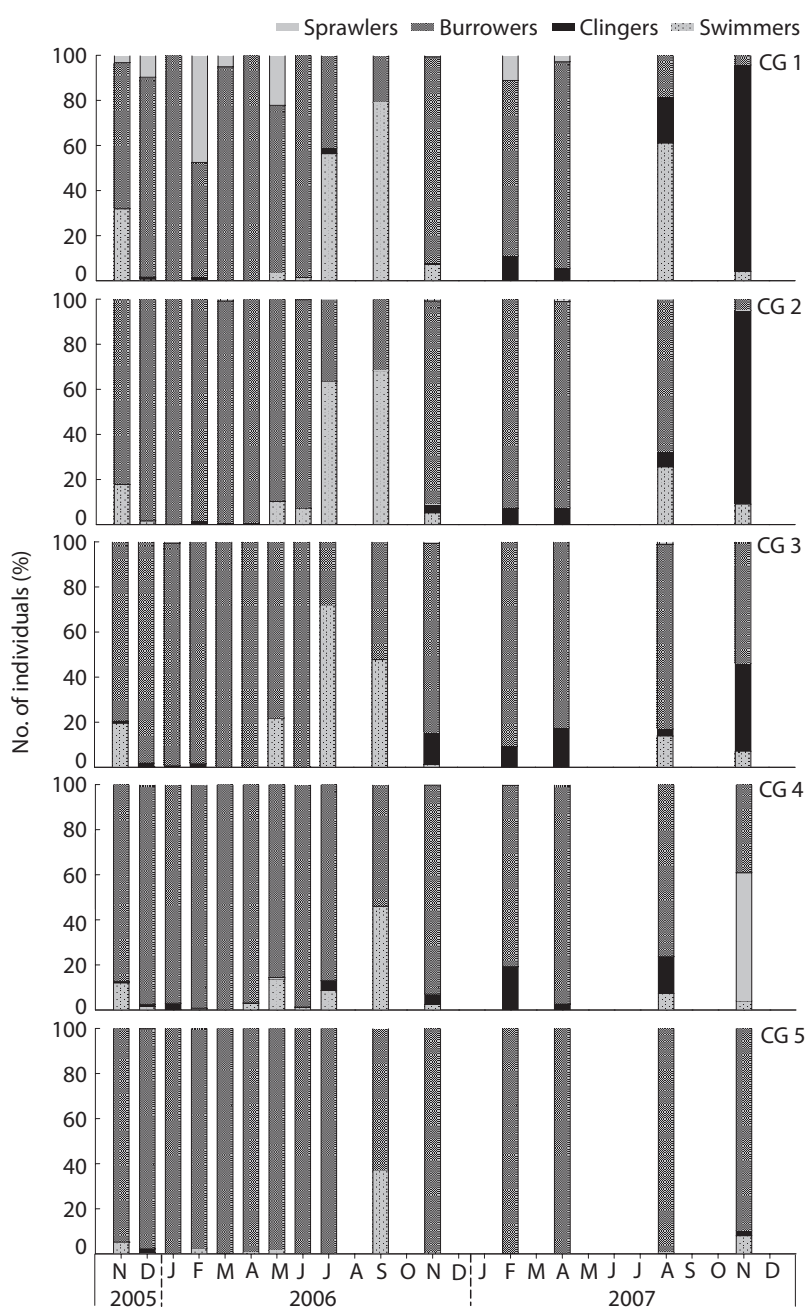

Fig. 6. Change in habitat orientation group compositions in Cheonggye (CG) Stream. Individual numbered data are based on the sum of three habitat samples (riffle, run/pool, and margin)

they were relatively more abundant in the lower stream sites and emerged in mass at certain sampling trials (e.g., November 2005 and November 2006 at CG 5 and June 2006 at CG3 for Chironominae sp. 1; April 2006 at CG3 and April 2007 at CG5 for Tubificidae sp.). A baetid mayfly (B. fuscatus) occurred more abundantly in the upper stream sites (CG1 and CG2) and peaked during the spring and summer. A psychodid fly (Pshchodidae sp.) occurred more abundantly during the spring. A leech species (Erpobdella lineate) colonized very rapidly at the upper stream sites (CG1 and CG2) over the initial time period, but their number decreased substantially after that time. In contrast, a caddisfly species (Cheumatopsyche brevilineata), appeared after almost 1 year in the upper and middle sites (CG1-CG3), but the individual number increased abruptly in November 2007 after a 2-year inter-

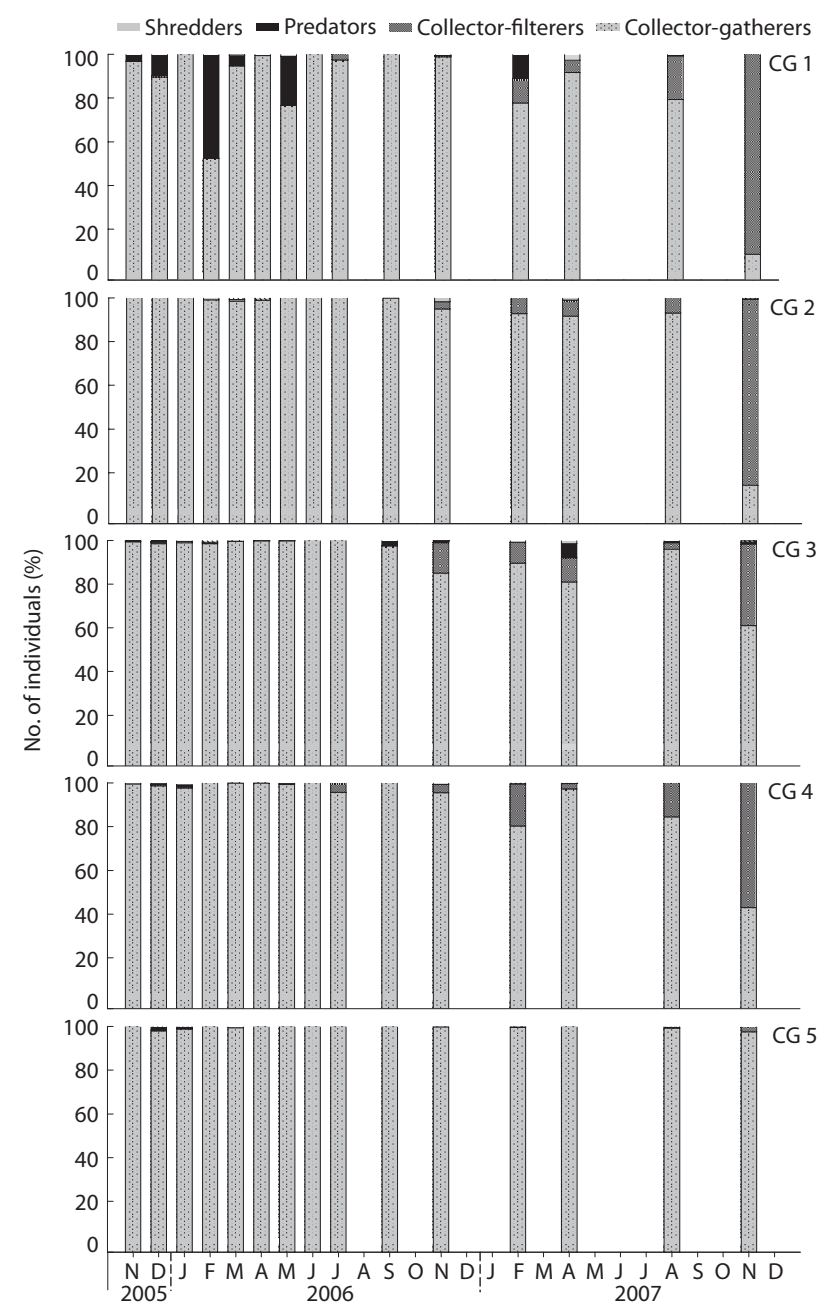

Fig. 7. Change in functional feeding group compositions in Cheonggye (CG) Stream. Individual numbered data are based on the sum of three habitat samples (riffle, run/pool, and margin)

val from the initial flow.

The habitat orientation groups changed with changes in density of the major benthic macroinvertebrate taxa, in particular the dominant species (Fig. 6). The swimmers (e.g., B. fuscatus) and clingers (e.g., E. lineate) colonized relatively rapidly in the upper stream sites over the period of a few months, but the burrowers (Chironominae sp. 1 and Tubificidae sp.) predominated throughout the study period, particularly in the lower stream sites. The habitat orientation groups also became more diverse, as a net-spinning caddisfly (C. brevilineata) became abundant in the upper and middle stream sites after 1 year.

Collector-gatherers and collector-filterers colonized first, followed by the scrapers, predators, and shredders (Fig. 7). Collector-gatherers (Chironominae sp. 1, Tubificidae sp., and B. fuscatus) were most abundant at all stream 
sites. Collector-filterers (C. brevilineata) abounded in the second year, and other functional feeding groups such as predators, scrapers (not seen in Fig. 7), and shredders

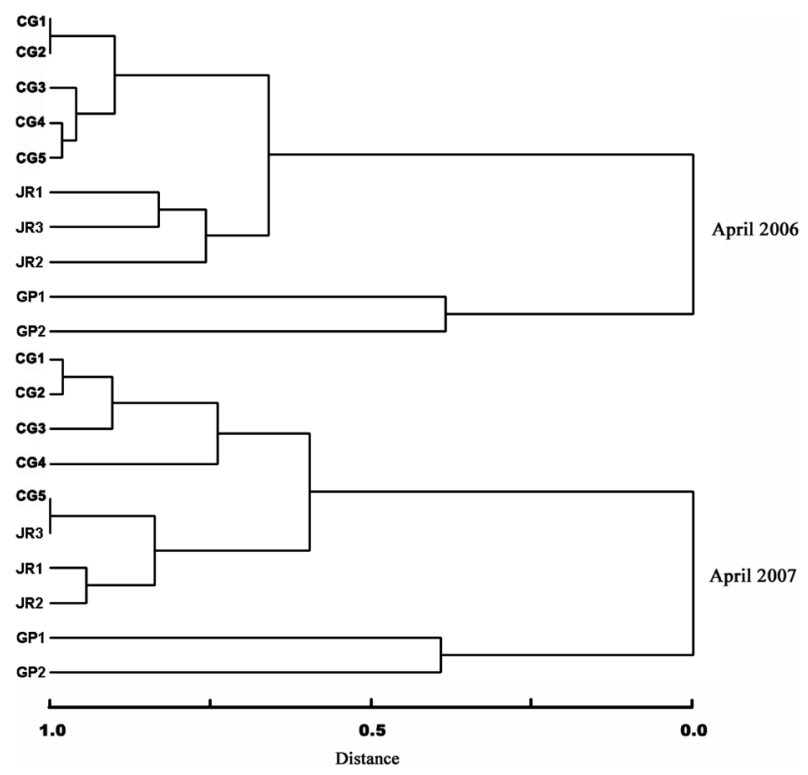

Fig. 8. Clustering of the Cheonggye (CG) Stream and two reference (JR, Jungnang; GP, Gapyeong) stream sites based on the benthic macroinvertebrate species presence/absence data from April 2006 and April 2007. Distances are Euclidean distances between farthest neighbors.

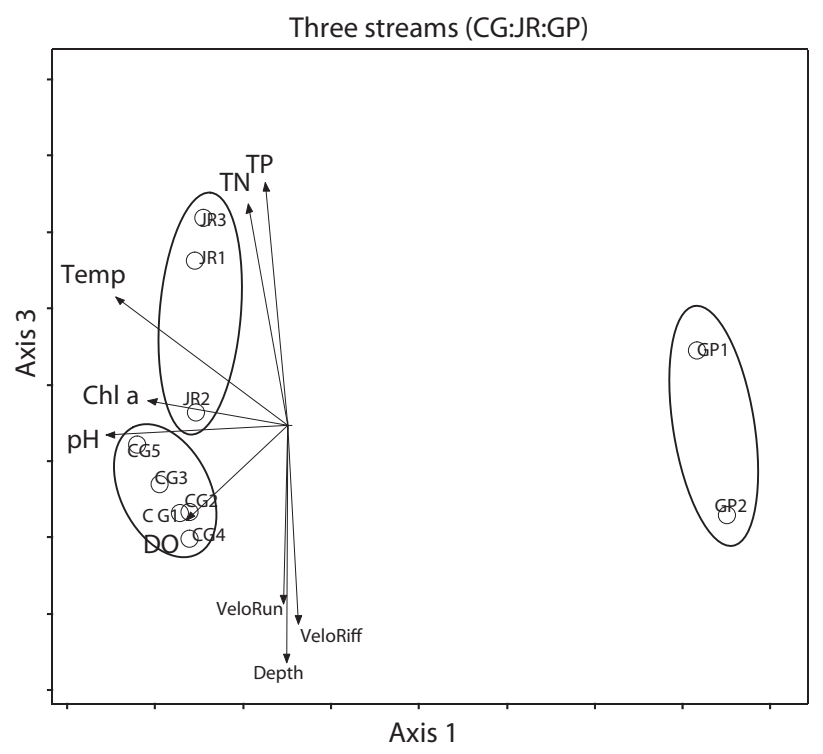

Fig. 9. Detrended correspondence analysis (DCA) ordination of benthic macroinvertebrate communities in the Cheonggye (CG1-CG5) Stream and two reference streams, Jungnang (JR1-JR3) and Gapyeong (GP1-GP2) streams. Individual numbered data are based on the sum of two habitat samples (riffle and run/pool) from the three streams. Arrows indicate the quantitative environmental factors as biplots. TP, total phosphorous; $\mathrm{TN}$, total nitrogen; Temp, water temperature; Chl a, chlorophyll $a$, DO, dissolved oxygen; VeloRun, velocity of run/pool; VeloRiff, velocity of riffle. were quite scarce at all stream sites throughout the study period.

The MRPP confirmed that the benthic macroinvertebrate communities of all Cheonggye Stream sites differed significantly ( $A=0.029, P=0.0021$ from the MRPP), but all Cheonggye Stream sites in November did not differ significantly ( $A=-0.027, P=0.0885$ from the MRPP). In contrast, the benthic macroinvertebrate communities of all streams (Cheonggye, Jungnang, and Gapyeong streams) sites differed significantly $(A=0.179, P=0.0449$ from MRPP) (Table 3).

The species composition cluster analyses for the first year (April 2006) also demonstrated that the benthic macroinvertebrate communities between the sites of the Cheonggye Stream (CG1-CG5) were clustered more closely than between those of the Jungnang Stream (JR1JR3) and Gapyeong Stream (GP1-GP2) (Fig. 8). The cluster analysis results for the second year (April 2007) were similar to those of the first year, except that the lower site of the Cheonggye Stream (CG5) was more closely clustered with the lower site of the Jungnang Stream (JR3).

We analyzed all three streams and all seasons with DCA to confirm the results of the cluster analysis. The first two axes of the DCA ordination accounted for the majority of the variation in the species data, with eigenvalues of 0.72 and 0.18 for axes 1 and 3, respectively, and a total inertia (total variation in the species data ) of 3.197. The macroinvertebrate communities of the Cheonggye and Jungnang streams were separated from those of the Gapyeong Stream, but not clearly separated by those from the Cheonggye and Jungnang streams (Fig. 9). We examined 11 quantitative environmental variables in the DCA, and our results showed that axis 1 was negatively correlated with water temperature $(r=-0.699)$, chlorophyll $a(r$ $=-0.630), \mathrm{pH}(r=-0.719), \mathrm{DO}(r=-0.538)$, and axis 3 was negatively correlated with depth $(r=-0.822)$, riffle velocity, run/pool velocity $(r=-0.753$ and $r=-0.713)$, DO $(r=$ $-0.521)$, and positively correlated with total nitrogen $(r=$ $0.793)$, and total phosphate $(r=0.831)$. From these Pearson and Kendall correlation variables, we found that the Cheonggye and Jungnang macroinvertebate communities were different from those of Gapyeong Stream, and that the main environmental factors for separation on the axis 1 were negatively correlated with water temperature, chlorophyll $a, \mathrm{pH}$, and DO (Fig. 9).

We only used the Cheonggye Stream November samples for 3 years $(2005,2006$, and 2007) to determine the annual changes in macroinvertebrates. Then, we examined the 11 quantitative environmental variables with the Cheonggye Stream macroinvertbrate community using 
NMS (Fig. 10). The results of the NMS ordination showed separation among the Cheonggye Stream communities; axis 1 and axis 2 explained $14 \%$ and $57 \%$ of the variance between sampling points, respectively. Axis 1 was positively correlated with water flow width $(r=0.614)$, water temperature $(r=0.678)$, conductivity $(r=0.561)$, total nitrogen $(r=0.491)$, total phosphate $(r=0.643)$, whereas

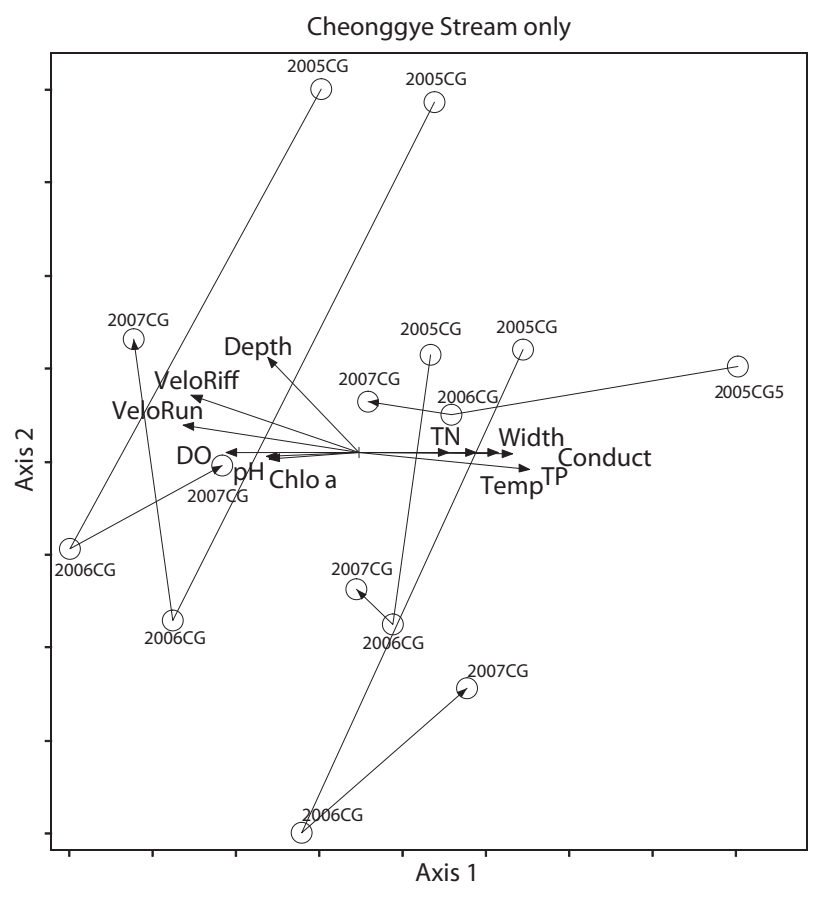

Fig. 10. Nonmetric multidimensional scaling (NMS) ordination of benthic macroinvertebrates (November 2005, November 2006, November 2007) in Cheonggye Stream (CG1-CG5). Individual numbered data are based on the sum of two habitat samples (riffle and run/pool) from the Cheonggye Stream only. Arrows indicate the quantitative environmental factors as biplots (minimized final stress, 17\%; final instability, 0.00036). Width, water flow width, depth; VeloRiff, velocity of riffle; VeloRun, velocity of run/pool; Temp, water temperature; DO, dissolved oxygen; Conduct, conductivity; TN, total nitrogen; TP, total phosphorous; Chlo a, chlorophyll $a$, and $\mathrm{pH}$.

Table 3. Results of multi-response permutation procedures (MRPP) to detect differences in species composition among (1) all Cheonggye Stream sites (from 2005 November to 2007 November, $N=75$ ), (2) all Cheonggye Stream sites in November (only November 2005, November 2006, and November 2007 samples, $N=15$ ), and (3) Cheonggye Stream $(N=5)$ and two other reference streams sites, Jungnang $(N=3)$ and Gapyeong streams $(N=2)$

\begin{tabular}{lccc}
\hline Streams & $\boldsymbol{T}$ & $\boldsymbol{A}$ & $\boldsymbol{P}$ \\
\hline (1) All Cheonggye sites & -3.578 & 0.029 & 0.0021 \\
(2) All Cheonggye for November & -1.389 & 0.027 & 0.0885 \\
(3) Cheonggye vs. Jungnang vs. Gapyeong & -2.021 & 0.179 & 0.0449 \\
\hline
\end{tabular}

$T$, test statistic; $A$, chance-corrected within-group agreement. axis 1 was negatively correlated with depth $(r=-0.496)$, riffle velocity $(r=-0.672)$, run/pool velocity $(r=-0.689)$, DO $(r=-0.599)$, chlorophyll $a(r=-0.491)$, and pH $(r=$ -0.499). Axis 2 was positively correlated with depth $(r=$ $0.507)$ and riffle velocity $(r=0.391)$, but the axis 2 correlation with other variables was very low. Changes in CG1-CG4 from 2005 to 2006, except CG5, were negatively correlated with axis 2 but the annual change in CG5 was negatively correlated with axis 1 .

\section{DISCUSSION}

\section{Colonizer sources}

Macroinvertebrate colonization in new stream reaches occurs via drift, aerial sources, hyporrheic sources, and upstream migration (Mackay 1992). The benthic macroinvertebrate fauna in the newly-built section of the Cheonggye Stream may have originated from a drift from upstream reaches (e.g., the Bukaksan Stream) during floods or from the Han River, the major origin of the water source. Possible migrants from the headwater streams include mountain stream-dwelling mayflies [e.g., Serratella ignita, Ecdyonurus levis, Epeorus pellucidus, and Choroterpes (Euthraulus) altioculus], stoneflies (Taenionema sp.), and caddisflies (Rhyacophila spp., Glossosoma KUa, and Goera japonica). These species were detected by chance in the upper and middle stream reaches, but no firm evidence was detected to suggest that these species successfully inhabited the restored section of the Cheonggye Stream.

However, the species occurring very abundantly throughout the restored stream section (e.g., Chironominae spp., B. fuscatus, Tubificidae sp., E. lineate, and Psychoda KUa) may have been introduced principally from the Han River water source via the transportation duct. Although the source water had undergone several purification steps, we collected abundant microscopic zooplankton and zoobenthos using a plankton net from the immediate outflow of the source water (Shin and Bae unpublished data). Some of these species (Chironominae spp., B. fuscatus, and Psychoda KUa) could have also arrived aerially or by drifting from the upstream reaches. A net-spinning caddisfly (C. brevilineata) may have possibly drifted from the upper stream reaches, as it was also found in Bukaksan Stream and successfully colonized during the second year. This hydropsychid caddisfly species commonly inhabits the middle stream reaches of natural streams in Korea, including the Gapy- 
eong Stream, which possesses abundant biomass (Bae et al. 2003).

Larvae of dragonflies (Anax parthenope julius, Orthetrum albistylum speciosum), damselflies (Ischnura asiatica, Cercion calamorum, Cercion hieroglyphicum, and Coenagrionoidae sp.), aquatic bugs (Ranatra chinensis), and aquatic beetles (Potamonectes hostilis, Potamonectes sp., Hydaticus sp., and Dytiscidae sp.) were found among the artificially planted aquatic plants along the stream margins during the initial study period. These aquatic insects belong to a typical lentic fauna in Korea and were probably introduced with aquatic plants when they were planted in the restored stream section. The majority of these species disappeared several months after their occurrence. The restored Cheonggye Stream was opened to the public on October 1, 2005, but pilot operations were conducted prior to the opening ceremony while the channel was under construction with artificial plantations.

\section{Colonization patterns}

Among the aquatic insects, the Baetidae (mostly Baetis) and Chironomidae are early colonizers in most studies of new or disturbed streams (Mackay 1992). Tubificid worms (Tubificidae sp.) are also abundant colonizers in urban streams. It appeared from our results that common and abundant species were early colonizers in the Cheonggye Stream. Swimmers and clingers colonized early, whereas net-spinning caddisflies took more than 1 year to settle in the restored Cheonggye Stream.

We detected an early dominance of collector-gatherers, including Baetidae and Chironomidae. This predominance of collector-gatherers (e.g., B. fuscatus and Chironomidae spp.) was predicted to be the food source in the form of fine particulate organic matter, which was abundant in the Cheonggye Stream. Although filter-feeders, including the hydropsychid caddisflies $(C$. brevilineata), increased in number during the second year, they were limited to the upstream reaches, where riffle habitats abounded. Grazers and scrappers appeared with low abundance, which may have been due to the physical stream channel structure of the Cheonggye Stream. As the Cheonggye Stream channel was constructed in the form of uniformly wide and flat-bottomed channels filled with sand and gravel, neither interstitial habitats for riffle macroinvertebrates nor suitable structures for periphyton development and leaf-pack accumulations were provided. Shredders have been reported as later colonizers than other detritivores and herbivores (Mackay 1992), but few shredders were observed in the Cheonggye Stream. This is because the coarse particulate organic matter, such as leaf litter from the upstream reaches into the restored channel, was limited. Although predators are recognized as late colonizers (Mackay 1992), few predators were found to have stably colonized in the Cheonggye Stream. This demonstrates that the Cheonggye Stream has a relatively simple food web structure compared with those of other natural streams.

\section{Community changes}

Although benthic macroinvertebrates in the Cheonggye Stream colonized rapidly, species richness was maintained at relatively low levels compared with other natural streams (Appendix 1). Other colonization studies conducted in new stream channels have shown that macroinvertebrates require 70 to 125 days to reach a similar level of density and community similarity to an upstream reach (Gore 1982, Mackay 1992). Cumulative species richness reached a maximum approximately 700 days after the opening of the new channel (Minshall et al. 1983, Mackay 1992). During a 2-year study period in the restored Cheonggye Stream, the density, species richness, and community structure changed, depending on season, location, and other unpredicted environmental factors, including floods (Table 3). Other anthropogenic effects, such as increases in tourism, stream bed cleaning for filamentous algae, etc., may have enhanced such unstable conditions.

In a survey conducted in the Cheonggye Stream prior to the restoration project in 1986 (as in Fig. 1c: before), only a few species of benthic macroinvertebrates, e.g., tubificid oligochaetes, psychodid fly larvae, and chironomid larvae, were detected inside the stream tunnel (Yoon et al. 1986). These organisms were considered very tolerant indicator species and are found only in very polluted water bodies, such as sewage channels (Rosenberg and Resh 1993). Considering this observation, changes in benthic macroinvertebrate communities after restoration projects can be substantial. However, compared with other urban streams (Jungnang Stream) and natural streams (Gapyeong Stream), the Cheonggye Stream currently shares more similarities with urban streams in terms of benthic macroinvertebrate community structure (Figs. 8 and 9). Diverse biotic and abiotic environmental factors could affect the structuring of the benthic macroinvertebrate communities in Cheonggye Stream and other reference streams. Physical environmental factors such as depth, current velocity, $\mathrm{DO}$, and $\mathrm{pH}$, as well 
as nutrient (total nitrogen and total phosphorous), water temperature, and conductivity factors could affect the distribution of benthic macroinvertebrates in the study streams, as shown in Figs. 9 and 10. These findings indicate that the restored Cheonggye Stream is a relatively unstable dynamic system compared to reference urban or natural streams.

\section{ACKNOWLEDGMENTS}

We thank the following researchers and graduate students of Korea University and Seoul Women's University who greatly assisted with the field trips: Hye Kyung Kil, Jeong Mi Hwang, Hwang Goo Lee, Young Hun Jin, Sang Woo Jung, Dong Gun Kim, Seon Yi Kim, and Min Jeong Baek. This work was supported by grant no. R01-2007000-20442-0 from the Basic Research Program of the Korea Science \& Engineering Foundation.

\section{LITERATURE CITED}

Alexander GG, Allan JD. 2006. Stream restoration in the upper Midwest, U.S.A. Restor Ecol 14: 595-604.

Allan JD, Castillo MM. 2007. Stream Ecology: Structure and Function of Running Waters. $2^{\text {nd }}$ ed. Springer, Dordrecht.

Bae YJ, Jin YH, Hwang JM, Nguyen VV, Hoang DH, Cao TKT. 2003. Distribution, habitat environment, and conservation of aquatic insects from the Gapyeong creek in Gyeonggi-do, Korea. Nat Conserv Res Korea 1: 1-25.

Bae YJ, Kil HK, Bae KS. 2005. Benthic macroinvertebrates for uses in stream biomonitoring and restoration. KSCE J Civ Eng 9: 55-63.

Bernhardt ES, Palmer MA. 2007. Restoring streams in an urbanizing world. Freshw Biol 52: 738-751.

Biondini ME, Mielke PW Jr, Berry KJ. 1988. Data-dependant permutation techniques for the analysis of ecological data. Vegetatio 75: 161-168.

Bis B, Zdanowicz A, Zalewski M. 2000. Effects of catchment properties on hydrochemistry, habitat complexity and invertebrate community structure in a lowland river. Hydrobiologia 422/423: 369-387.

Brown KB. 2000. Urban Stream Restoration Practices: An Initial Assessment. Center for Watershed Protection, Elliot City, MD.

Clarke KR. 1993. Non-parametric multivariate analyses of changes in community structure. Aust J Ecol 18: 117143.

Gore JA. 1982. Benthic invertebrate colonization: source dis- tance effects on community composition. Hydrobiologia 94: 183-193.

Hill MO, Gauch HG. 1980. Detrended correspondence analysis: an improved ordination technique. Vegetatio 42: 4758.

Kawai T, Tanida K. 2005. Aquatic Insects of Japan: Manual with Keys and Illustrations. Tokai University Press, Kanagawa.

Kruskal JB. 1964. Nonmetric multidimensional scaling: a numerical method. Psychometrika 29: 115-129.

Mackay RJ. 1992. Colonization by lotic macroinvertebrates: a review of processes and patterns. Can J Fish Aquat Sci 49: 617-628.

Malmqvist B, Rundle S, Brönmark C, Erlandsson A. 1991. Invertebrate colonization of a new, man-made stream in southern Sweden. Freshw Biol 26: 307-324.

Mather PM. 1976. Computational Methods of Multivariate Analysis in Physical Geography. Wiley, London.

McCafferty WP. 1981. Aquatic Entomology: the Fishermen's Guide and Ecologists' Illustrated Guide to Insects and Their Relatives. John \& Bartlett, Boston.

McCune B, Grace JB. 2002. Analysis of Ecological Communities. MjM Software Design, Gleneden Beach, OR.

McCune B, Mefford MJ. 1999. PC-ORD: Multivariate Analysis of Ecological Data. Version 4. MjM Software Design, Gleneden Beach, OR.

Merritt RW, Cummins KW. 1996. An Introduction to the Aquatic Insects of North America. $3^{\text {rd }}$ ed. Kendall/Hunt Pub. Co., Dubuque, IA.

Minshall GW, Andrews DA, Manuel-Faler CY. 1983. Application of island biogeographic theory to streams: macroinvertebrate recolonization of the Teton River, Idaho. In: Stream Ecology: Application and Testing of General Ecological Theory (Barnes JR, Minshall GW, eds). Plenum Press, New York, pp 279-297.

Moerke AH, Gerard KJ, Latimore JA, Hellenthal RA, Lamberti GA. 2004. Restoration of an Indiana, USA, stream: bridging the gap between basic and applied lotic ecology. J N Am Benthol Soc 23: 647-660.

Muotka T, Paavola R, Haapala A, Novikmec M, Laasonen P. 2002. Long-term recovery of stream habitat structure and benthic invertebrate communities from in-stream restoration. Biol Conserv 105: 243-253.

Nakano D, Nagayama S, Kawaguchi Y, Nakamura F. 2008. River restoration for macroinvertebrate communities in lowland rivers: insights from restorations of the Shibetsu River, north Japan. Landsc Ecol Eng 4: 63-68.

Purcell AH, Friedrich C, Resh VH. 2002. An assessment of a small urban stream restoration project in Northern California. Restor Ecol 10: 685-694. 
Quinn JM, Williamson RB, Smith RK, Vickers ML. 1992. Effects of riparian grazing and channelisation on streams in Southland, New Zeland. 2. Benthic invertebrates. N Z J Mar Freshw Res 26: 259-273.

Rosenberg DM, Resh VH. 1993. Freshwater Biomonitoring and Benthic Macroinvertebrates. Chapman \& Hall, New York, NY.

SAS Institute. 2001. PROC User's Manual. $6^{\text {th }}$ ed. SAS Institute, Cary, NC.

Smith RL, Smith TM. 2001. Ecology and Field Biology. $6^{\text {th }}$ ed. Benjamin Cummings, San Francisco, CA.

Sokal RR, Rohlf FJ. 1994. Biometry: The Principles and Practices of Statistics in Biological Research. $3^{\text {rd }}$ ed. W. H.
Freeman, New York, NY.

Ward JV. 1992. Aquatic Insect Ecology. John Wiley \& Sons Inc., New York, NY.

Wiederholm T. 1983. Chironomidae of the Holarctic region. Part 1. Larvae. Entomol Scand Suppl 19: 1-457.

Wilkinson L. 1988. Systat: The System for Statistics. Syatat Inc., Evanston, IL.

Williams DD, Feltmate BW. 1992. Aquatic Insects. CBA International, Oxon.

Yoon IB. 1995. Aquatic Insects of Korea. Jeonghaengsa, Seoul. Yoon IB, Bae YJ, Aw SJ. 1986. The fauna in the closed watercourse section of Chonggye stream in Seoul. Nat Conserv 54: 35-40. 
Appendix 1. Individual number of benthic macroinvertebrates quantitatively sampled from Cheonggye Stream and the reference streams

\begin{tabular}{|c|c|c|c|c|c|c|c|c|c|c|c|c|}
\hline \multirow{2}{*}{ Species } & \multicolumn{5}{|c|}{ CG } & \multicolumn{3}{|c|}{ JR } & \multicolumn{2}{|c|}{ GP } & \multirow{2}{*}{ BA } & \multirow{2}{*}{ HR } \\
\hline & CG1 & CG2 & CG 3 & CG 4 & CG5 & JR1 & JR2 & JR3 & GP1 & GP2 & & \\
\hline \multicolumn{13}{|l|}{ Turbellaria } \\
\hline Dugesia japonica & 2 & & 7 & & & & & & 1 & & & \\
\hline \multicolumn{13}{|l|}{ Gastropoda } \\
\hline Physa acuta & 48 & 20 & 30 & 5 & 1 & & 1 & & & & 1 & \\
\hline Austropeplea ollula & & & 1 & & & & & & & & & \\
\hline Semisulcospira gottschei & 2 & & & 2 & & & & & & & & 10 \\
\hline \multicolumn{13}{|l|}{ Archioligochaeta } \\
\hline Tubificidae sp. & 1,107 & 523 & 5,432 & 2,590 & 8,305 & 3,191 & 96 & 7,114 & 1 & & 75 & 150 \\
\hline Chaetogaster limnaei & & & 1 & 2 & & & & & & 1 & 1 & \\
\hline \multicolumn{13}{|l|}{ Hirudinea } \\
\hline Alboglossiphonia lata & & 1 & 54 & 7 & 100 & & 26 & & & & & \\
\hline Alboglossiphonia sp. & & & & & & & & & & & & 2 \\
\hline Glossiphoniidae sp. & & & & & 8 & & & & & & & \\
\hline Helobdella stanalis & & & & 1 & & & & & & & & \\
\hline Helobdella sp. & & & & & & & & & & & & 3 \\
\hline Erpobdella lineata & 308 & 141 & 336 & 136 & 95 & 1 & 28 & 1 & & & 4 & 4 \\
\hline \multicolumn{13}{|l|}{ Pelecypoda } \\
\hline Corbicula fluminea & & & & & & & & & & & & 1 \\
\hline Limnoperna fortunei & & & & & & & & & & & & 3 \\
\hline \multicolumn{13}{|l|}{ Crustacea } \\
\hline Gammarus sp. & & & & & & & & & & 52 & 40 & \\
\hline Palaemon miyadii & & & & & & & & & & & & 1 \\
\hline Asellus sp. & & & 2 & 27 & 1 & & & & & & & \\
\hline \multicolumn{13}{|l|}{ Ephemeroptera } \\
\hline Ameletus costalis & & & & & & & & & & 5 & & \\
\hline Ameletus montanus & & & & & & & & & & 1 & & \\
\hline Acentrella gnom & & & & & & & & & 1 & 59 & & \\
\hline Acentrella sibirica & & & & & & & & & 1 & & & \\
\hline Baetiella tuberculata & & & & & & & & & 31 & & & \\
\hline Baetis fuscatus & 1,236 & 1,293 & 1,009 & 777 & 444 & & 1 & & & 3 & & \\
\hline Baetis silvaticus & & & & & & & & & & 102 & & \\
\hline Baetis pseudothermicus & & 1 & & & 1 & & & & & & & \\
\hline Baetis ursinus & 3 & 3 & 14 & 2 & & & & & & & & \\
\hline Labiobaetis atrebatinus & & 3 & 5 & 5 & 3 & & & & & & & \\
\hline Nigrobaetis acinaciger & & & & & & & & & 1 & & & \\
\hline Nigrobaetis bacillus & & & & & & & & & 2 & 53 & 283 & \\
\hline Cincticostella levanidovae & & & & & & & & & 12 & 7 & & \\
\hline Cincticostella tshernovae & & & & & & & & & 7 & & & \\
\hline Drunella aculea & & & & & & & & & 28 & 7 & & \\
\hline Drunella cryptomeria & & & & & & & & & 1 & & & \\
\hline Serratella setigera & & & & & & & & & & 2 & & \\
\hline Serratella ignita & 1 & & & & & & & & & & & \\
\hline Uracanthella rufa & & & & & & & & & 52 & & & \\
\hline Potamanthellus chinensis & & & & & & & & & & & & 6 \\
\hline Potamanthus formosus & & & & & & & & & & & & 11 \\
\hline Ephemera separigata & & & & & & & & & & 8 & & \\
\hline Ephemera strigata & & & & & & & & & 1 & 20 & & \\
\hline Ephemera orientalis & & & & & & & & & & & & 45 \\
\hline
\end{tabular}


Appendix 1. Continued

\begin{tabular}{|c|c|c|c|c|c|c|c|c|c|c|c|c|}
\hline \multirow{2}{*}{ Species } & \multicolumn{5}{|c|}{ CG } & \multicolumn{3}{|c|}{ JR } & \multicolumn{2}{|c|}{ GP } & \multirow{2}{*}{ BA } & \multirow{2}{*}{ HR } \\
\hline & CG1 & CG2 & CG 3 & CG 4 & CG5 & JR1 & JR2 & JR3 & GP1 & GP2 & & \\
\hline Ecdyonurus kibunensis & & & & & & & & & 47 & 136 & & \\
\hline Ecdyonurus levis & & & & 1 & & & & & 1 & 1 & & \\
\hline Ecdyonurus dracon & & & & & & & & & 67 & & & \\
\hline Ecdyonurus bajkovae & & & & & & & & & 16 & 14 & 1 & \\
\hline Epeorus curvatulus & & & & & & & & & 73 & 115 & 2 & \\
\hline Epeorus pellucidus & & & & 2 & & & & & 133 & & & \\
\hline Heptagenia kihada & & & & & & & & & & & 2 & \\
\hline Cinygmula grandifolia & & & & & & & & & & 4 & & \\
\hline Choroterpes (Euthraulus) altioculus & 2 & 1 & & & 1 & & & & 61 & & 1 & \\
\hline Paraleptophlebia chocolate & & & & & & & & & 158 & 141 & & \\
\hline Caenis KUa & & & 2 & & & & & & 4 & & & 2 \\
\hline \multicolumn{13}{|l|}{ Odonata } \\
\hline Ischnura asiatica & & & 13 & & 10 & & & & & & & \\
\hline Cercion calamorum & & & & & 2 & & & & & & & \\
\hline Cercion hieroglyphicum & & & 2 & & 2 & & & & & & & \\
\hline Coenagrionoidae sp. & & & 3 & & & & & & & & & \\
\hline Anax parthenope Julius & & & & & 1 & & & & & & & \\
\hline Orthetrum albistylum speciosum & & & 3 & 1 & 2 & & & & & & & \\
\hline Davidius lunatus & & & & & & & & & 1 & & 2 & \\
\hline Anisogomphus maacki & & & & & & & & & & 1 & & \\
\hline Sieboldius albardae & & & & & & & & & 1 & & & \\
\hline \multicolumn{13}{|l|}{ Plecoptera } \\
\hline Neoperla coreensis & & & & & & & & & 16 & 4 & & \\
\hline Taenionema sp. & & & 1 & & & & & & & & 3 & \\
\hline Rhopalopsole mahunkai & & & & & & & & & & 1 & & \\
\hline Kamimuria coreana & & & & & & & & & & 1 & & \\
\hline Oyamia nigribasis & & & & & & & & & 1 & 144 & & \\
\hline Nemoura tau & & & & & & & & & & 1 & & \\
\hline Amphinemura KUb & & & & & & & & & & 1 & & \\
\hline Sweltsa nikkoensis & & & & & & & & & 8 & 51 & 10 & \\
\hline Yoraperla KUa & & & & & & & & & & 1 & & \\
\hline \multicolumn{13}{|l|}{ Hemiptera } \\
\hline Ranatra chinensis & & & 1 & & & & & & & & & \\
\hline \multicolumn{13}{|l|}{ Coleoptera } \\
\hline Potamonectes hostilis & & 1 & 2 & & & & & & & & & \\
\hline Potamonectes sp. & & 3 & 12 & 3 & & & & & & & & \\
\hline Hydaticus sp. & & & 2 & & & & & & & & & \\
\hline Dytiscidae sp. & 1 & & & 1 & & & & & & & & \\
\hline Stenelmis sp. & & & & & & & & & & 3 & & 1 \\
\hline Zaitzevia sp. & & & & & & & & & 1 & & & \\
\hline \multicolumn{13}{|l|}{ Diptera } \\
\hline Simulium sp. & & & 1 & & & & & & 3 & 12 & & \\
\hline Tipula KUb & 4 & & 7 & 7 & 1 & & & & & & & \\
\hline Tipula sp. & & 2 & & 1 & & & & & & & & \\
\hline Antocha KUa & 3 & & 2 & 2 & 1 & & & & 10 & 4 & & 3 \\
\hline Pedicia KUa & & & & & & & & & 31 & & & \\
\hline Hexatoma KUa & & & & & & & & & 1 & 8 & & \\
\hline Suragina KUb & & & & & & & & & 8 & 8 & & \\
\hline
\end{tabular}


Appendix 1. Continued

\begin{tabular}{|c|c|c|c|c|c|c|c|c|c|c|c|}
\hline \multirow{2}{*}{ Species } & \multicolumn{5}{|c|}{ CG } & \multicolumn{3}{|c|}{ JR } & \multicolumn{2}{|c|}{ GP } & \multirow{2}{*}{ BA } \\
\hline & CG1 & CG2 & CG 3 & CG 4 & CG5 & JR1 & JR2 & JR3 & GP1 & GP2 & \\
\hline Tabanus sp. & 1 & & & & 2 & & & & & & \\
\hline Empidinae sp. & & & & & & & & & & 1 & \\
\hline \multicolumn{12}{|l|}{ Dolichopodidae sp. } \\
\hline Ceratopogonidae sp. & 3 & 3 & 2 & 3 & & & & & 2 & 9 & \\
\hline Chironominae sp. 1 & 1,870 & 2,722 & 7,458 & 6,975 & 7,198 & 377 & 2,931 & 4,092 & 63 & 1,323 & 13 \\
\hline Chironominae sp. 2 & 324 & 608 & 633 & 1,633 & 382 & & 49 & 5 & 9 & 11 & 1 \\
\hline Chironominae sp. 3 & 74 & 12 & 250 & 28 & 181 & 32 & 58 & 57 & & & 7 \\
\hline Tanypodinae sp. & 26 & 32 & 166 & 113 & 28 & & 3 & & 16 & 46 & 272 \\
\hline Psychoda KUa & 447 & 206 & 489 & 163 & 111 & & & & & & \\
\hline Telmatoscopus KUa & 3 & 1 & 4 & & 2 & & & & & & \\
\hline Muscidae sp. & 160 & 2 & 5 & & & & & & & & \\
\hline Emphydridae sp. & & 1 & & & & & & & & & \\
\hline
\end{tabular}

\section{Trichoptera}

Stenopsyche bergeri

Hydropsyche kozhantschikovi

Hydropsyche orientalis

Hydropsyche sp.

Cheumatopsyche brevilineata

Cheumatopsyche $\mathrm{KUb}$

Rhyacophila brevicephala

Rhyacophila nigrocephala

Rhyacophila articulate

Rhyacophila KUa

Hydroptila KUa

Phryganopsyche latipennis

Apatania KUa

Goerodes KUb

Glossosoma KUa

Goera japonica

$\begin{array}{rrrrr}9 & & 2 & 11 & 1 \\ 1 & & 4 & & 2 \\ 1 & & 2 & 2 & \\ 1,776 & 609 & 424 & 598 & 18 \\ & & 2 & & \\ & 2 & & & \\ 2 & & & & \end{array}$

$$
2
$$

Hydatophylax nigrovittatus

Ecnomus tenellus

Wormaldia KUa

Psilotreta locumtenens

Neophylax ussuriensis

Mystacides KUa

Ceraclea lobulata

$\begin{array}{llll}2 & & & \\ 23 & 1 & \\ & & & \\ 6 & & 1 \\ & & & \\ 2 & 1 & 2 \\ 6 & & \\ & 1 & \\ & 2 & \end{array}$

$\begin{array}{lll}6 & 11 & 20\end{array}$

\section{Lepidoptera}

Noctuidae sp.

Total species

Cheonggye (CG) Stream data are based on 15 sampling trials from November 2005 to November 2007. Jungnang (JR) and Gapyeong (GP) stream data are based on two sampling trials in April 2006 and April 2007. Bukaksan (BA) Stream and Han River (HR) data are based on a single sampling trial in October 2006. Cheonggye Stream data are based on the sum of three habitat samples (riffle, run/pool, and margin), whereas other stream data are the sum of two habitat samples (riffle and run/pool). 